\title{
Accounting Research in the Japanese Setting*
}

\author{
Douglas J. SKInNeR ${ }^{\dagger}$ \\ Booth School of Business \\ UNIVERSITY OF CHICAGO
}

\begin{abstract}
In this commentary I offer some thoughts on the possibilities for accounting research that uses the Japanese setting. I argue that the uniqueness of the Japanese setting offers many opportunities for researchers, and hope that we can encourage more researchers to take advantage of this setting to advance the literature on financial reporting and disclosure.
\end{abstract}

I am honored that Professor Yamaji has asked me to write a commentary for the first issue of The Japanese Accounting Review (TJAR). The goal of my commentary is to highlight the importance of doing accounting research that uses the Japanese setting, focusing on my main area of expertise, which is the capital markets area, and more specifically on the way that corporate managers communicate with capital markets through financial reporting and disclosure as well as through corporate payout policy. This includes earnings management and disclosure, areas of prominence in the mainstream North American literature over the last 20 years.

To this point I have worked on four projects that focus on Japanese capital markets. The topics include earnings management, management forecasts (disclosure), auditing, and corporate payout policy. ${ }^{1} \mathrm{I}$ am sometimes asked why I am doing research on Japanese companies, something that is unusual in the mainstream North American accounting journals. The answer is quite simple: the Japanese setting allows me to identify unique or unusual institutional features that I can use to answer questions that cannot be answered using data from the U.S. or similar institutional settings. The goal of this research is not to focus on Japan for the sake of doing so. Instead, the point is to find open questions in the literature that we can answer by exploiting unusual features of the Japanese environment, and so provide insights not available elsewhere. The beauty of Japan is that it is truly unique, so there are lots of opportunities for doing this type of work. Let me provide a couple of

\footnotetext{
* This commentary was solicited by Professor Hidetoshi Yamaji, Editor-in-Chief of The Japanese Accounting Review, who has given me useful comments on an earlier draft. I am grateful for the opportunity to write this commentary, which I would like to dedicate to the memory of our colleague, Professor Kazuyuki Suda of Waseda University, who passed away earlier this year. I am grateful to the University of Chicago, Booth School of Business, for financial support.

$\dagger$ Corresponding Author. Address University of Chicago 5807 South Woodlawn Avenue Chicago, IL 60637-1610, USA. Telephone + 773 702-7137 E-mail dskinner@ chicagobooth.edu

1 Skinner (2008), Kato et al. (2009), Skinner and Srinivasan (2010), and Kato et al. (2011).
} 
examples from my own research. ${ }^{2}$

In 1998, I published a paper on deferred tax accounting that used U.S. data to investigate whether the valuation allowance for deferred tax assets was used by managers for earnings management purposes (Miller and Skinner, 1998). We found little evidence that this was the case. However, for reasons that are not uncommon in the earnings management literature, that setting was not very powerful, in part because we could not develop clear predictions about the direction in which managers might be managing earnings. A few years later I found myself teaching an MBA class on financial accounting to a group of Japanese and Korean managers. To make the class more useful to the students, I asked them to bring in copies of their companies' annual reports. One of these reports was from a large Japanese bank, and I soon noticed the bank's large deferred tax assets. This discovery led me on a long journey that led to Skinner (2008), which examines the role of deferred tax accounting in the Japanese financial crisis of the 1990s. This was a setting where accounting had large economic consequences, not only for Japanese banks but also for the Japanese financial sector as a whole-without being able to include a substantial amount of deferred tax assets in their regulatory capital, many of the largest Japanese banks would have collapsed, potentially wreaking havoc on the economy. Strikingly, this issue arose again in the recent financial crisis in the U.S., with Citigroup including $\$ 14$ billion of deferred tax assets in its Tier I regulatory capital at September 30, 2009. There is currently some controversy about how Basel III should treat deferred tax assets, with a recent Harvard case focusing on this issue in the context of the Japanese experience (Hawkins et al., 2011).

While the Japanese setting offers many opportunities, there are challenges as well. In particular, for someone such as myself who is not Japanese and has not lived in Japan, it is costly to be sure that one fully understands the Japanese institutional setting. To do this requires a large investment in time, both in reading the relevant academic and institutional literature on Japan, as well as consulting with as many Japanese academics and practitioners as possible. For the deferred tax paper I was able to rely on the generous support of a group of Japanese MBA students at the University of Michigan (where I then was) as well as a network of contacts in Japanese academia and business, notable among them being the late Professor Kazuyuki Suda of Waseda University. Another way of addressing this issue is to involve Japanese co-authors, who have a natural advantage in this regard.

I took this approach in my next Japanese project, which is co-authored with Professor Kazuo Kato of the Osaka University of Economics and Professor Michio Kunimura of Meijo University (Kato et al., 2009). Since early papers by Patell (1976) and Penman (1980), a large literature in accounting has developed that looks at management earnings forecasts. In most countries such forecasts are voluntarily issued, which means that any consideration of the capital market effects of these forecasts must take into account managers' incentives to release the forecasts (Verrecchia, 1983). In Japan, however, these forecasts are effectively mandated, which changes the nature of the setting considerably, and allows us to examine how the mandatory nature of the disclosure affects both the nature of the forecasts that management provides and their information content. ${ }^{3}$

My third and final example is ongoing work with Suraj Srinivasan, of Harvard Business School. Suraj and I study events surrounding the demise of ChuoAoyama, formerly the Japanese affiliate of Pricewaterhouse Coopers, and one of the "Big Four" audit firms in Japan. We analyze how ChuoAoyama's clients responded to events associated with the revelation of an audit failure

2 The goal of this commentary is not to provide a review of the literature, so I apologize in advance for not citing the full set of papers that utilize the Japanese setting to address open questions in accounting.

3 An early paper by Darrough and Harris (1991) had taken a similar approach, but the available data and environment changed considerably over the two decades between these studies. 
at Kanebo, a large Japanese cosmetics firm that revealed a massive accounting fraud in 2004. An important but unresolved issue in the auditing literature is to identify the forces that drive auditors' incentives to deliver high quality audits (those likely to reveal accounting problems and improprieties). The literature focuses on two main types of incentives-a litigation/insurance incentive and a reputation incentive. Under the litigation/insurance argument, the fact that auditors can be sued for large monetary damages in the event of audit failures provides them with incentives to deliver quality. Under the reputation argument, auditors' fees depend on their reputation for quality, with a likely fee premium available for high quality audits. Empirically, differentiating between these arguments is difficult because in most countries litigation and reputation effects are both likely to be important. Because of Japan's very different legal environment, however, the litigation role can effectively be ruled out, allowing us to examine the reputation argument more directly. ${ }^{4}$

Given the advantages of doing research in Japan, it is puzzling to me that there is not more research that uses this setting. One obvious issue is that the uniqueness of the Japanese setting is both a blessing and a curse. The blessings I have already described. The curse is that it is sometimes difficult to convince reviewers and editors that results from Japan have implications for other settings; that is, the external validity of this research is subject to question. Moreover, fundamental differences between the nature of western economies and that of Japan make it hard to draw strong policy implications about observed differences in financial reporting and disclosure practices-it is hard to conclude, for example, that Japan will necessarily be better off by instituting western-style accounting and corporate governance practices if other aspects of the economy remain uniquely Japanese. That is, there are likely to good reasons why the Japanese financial reporting system has evolved differently from those in western countries (e.g., see Yamaji, 1999).

This does not mean, however, that research in this type of different setting cannot provide useful empirical evidence about the effects of different institutional features of the economy. First, in accounting, there is an increasing amount of research from non-U.S. settings that speaks to open research questions in the literature. For example, research using unusual features of the Chinese setting has flourished over the last ten years. To take just one example, Tang (2011) provides evidence on the effects of disclosure by looking at price differences between A and B shares of Chinese firms. $\mathrm{A}$ and $\mathrm{B}$ shares have equal cash flow and voting rights, but trading in these shares is restricted to different sets of investors who face different information environments, which provides a useful setting in which to consider the effects of disclosure on securities pricing. If researchers are careful to provide details about the nature of the institutional setting, there is no reason that research such as this cannot provide useful insights into open questions in the literature.

Second, for some time researchers in corporate finance have exploited the unusual nature of the Japanese setting to provide new insights into important theoretical issues in that literature. Examples include Hoshi et al. (1990), Kaplan and Minton (1994), Dewenter and Warther (1998), and Pinkowitz and Williamson (2001). With some exceptions (e.g., Gramlich et al. 2004), there has not been a great deal of accounting research that uses the Japanese setting in this way. I think this provides an opportunity for researchers in accounting.

A word of warning is probably useful here. It is not sufficient merely to replicate studies done in other countries such as the U.S. or U.K. using Japanese data. Although this might be somewhat informative (e.g., in telling us whether results are robust to different settings), it will not be of great

4 Weber et al. (2008) take a similar approach in the German setting, where auditors' legal liability is limited to relatively small monetary amounts. Other authors who examine the events surrounding the suspension and collapse of ChuoAoyama include Numata and Takeda (2010) and Murase et al. (2011). 
interest to researchers outside of Japan. Instead, knowledge of the different institutional features available in Japan can be utilized to craft research questions that allow us to address open questions in the literature in ways not possible with data from other countries. By providing new insights into questions of interest to researchers around the world, research in Japan can potentially yield big payoffs.

For researchers not familiar with the Japanese setting, it is probably useful to provide some sense for how Japan's capital markets are different. One important feature of this setting that has received a lot of attention is the unusual nature of corporate groups in Japan, as characterized by the existence of relatively large corporate cross-holdings, the central role of banks in many of these groups, with related implications for financing, and the existence of both horizontal and vertical keiretsu structures. $^{5}$ As discussed more fully elsewhere (e.g., Hoshi and Kashyap, 2001), these features allow Japanese companies to resolve the adverse selection and moral hazard problems ("agency problems") that we worry so much about in western economies in very different ways, which has implications for financial reporting and auditing. For example, by having a main bank at the center of corporate groups, private information is shared between companies and the banks that finance them, mitigating information asymmetries.

While the very different Japanese system worked well in the 1960s, 1970s, and 1980s, large questions arose in the mid to late 1990s, after the bubble in Japanese stock and real estate prices burst, leading to the "lost decade" (Fukao, 2003; Hoshi and Kashyap, 2001). As a result of these concerns, the Japanese Government instituted financial reforms on a large scale; these reforms were collectively referred to at the "Big Bang." These reforms occurred throughout the Japanese financial system, but include reforms of corporate governance, financial reporting, and auditing. Many of these reforms involved the adoption of what was essentially a western governance model. For example, in 2001 regulators set up the Accounting Standards Board of Japan (ASBJ), which in many ways is modeled after the U.S. Financial Accounting Standards Board (FASB). Many of the rules adopted by the ASBJ are based on those from the U.S. or U.K. Auditing reforms are also moving auditing practice in Japan towards what are seen to be superior western models.

These changes offer many opportunities for researchers in accounting. Rarely do we have a setting where there are important changes in accounting rules, the institutional environment, auditing practice, and so on. While much research addresses the effects of the introduction of IFRS in various countries around the world (e.g., Daske et al., 2008), the associated changes are in many cases actually quite modest. For example, in countries such as Canada, the U.K., and Australia, it is hard to imagine that IFRS changed the accounting infrastructure very much given the similarity of IFRS to the GAAP rules that previously existed in those countries, as well as the relatively high quality financial reporting infrastructure (e.g., auditing and securities law enforcement). In contrast, I would argue that Japan's accounting rules have changed quite radically over the past 15 years; for example, Japanese companies were not required to prepare and issue consolidated financial statements until about ten years ago.

A number of researchers have emphasized the importance of the institutional setting in understanding the effect of changes in accounting. As Ball et al. (2003) discuss, it is likely to be difficult to understand the effect of changes in accounting rules around the world without also considering the nature of the associated enforcement regimes-changes in accounting rules are not likely to be effective unless they are properly monitored and enforced. In Japan, there have been significant changes not only in the accounting rules, but also in many of the underlying institutions.

\footnotetext{
5 Two useful references here are Hoshi and Kashyap (2001) and Aoki et al. (1994) but much has been written on this topic.
} 
By carefully examining the nature of these changes, as well as exploiting differences in their timing and cross-sectional variation in their impact, we are likely to be able to learn more about causal relationships between the nature of accounting and disclosure on the one hand and capital markets on the other. It is much more difficult to do this in economies (such as those of the U.S., U.K, Canada, etc.) where there is relatively little time-series or cross-sectional variation.

In closing, the Japanese setting offers accounting researchers-both those within Japan and those from other countries-many opportunities to address important open research questions in financial reporting and disclosure. I am optimistic that TJAR will help to open the door for more of this research in the future, and so play an important role in advancing knowledge in our field.

\section{REFERENCES}

AOKI, M., H. PATRICK, AND P. SHEARD. 1994. The Japanese main bank system: An introductory overview. In: AOKI M., AND H. PATRICK. eds. The Japanese Main Bank System. Oxford, UK: Oxford University Press.

BALL, R., A. RoBIN, AND J. WU. 2003. Incentives versus standards: Properties of accounting income in four East Asian countries. Journal of Accounting and Economics 36 (December): 235-270.

DASKE, H., L. HAIL, C. LEUZ, AND R. VERDI. 2008. Mandatory IFRS Reporting around the world: Early evidence on the economic consequences. Journal of Accounting Research 46 (December): 1085-1142.

DARrough, M. N., AND T. S. HARRIS. 1991. Do management forecasts of earnings affect stock prices in Japan? In: ZIEMBA, W.T., W. BAILEY, AND Y. HAMAO. eds. Japanese Financial Market Research. Amsterdam, THE NETHERLANDS: North Holland.

DEWENTER, K. L., AND V. A. WARTHER. 1998. Dividends, asymmetric information, and agency conflicts: Evidence from a comparison of the dividend policies of Japanese and U.S. firms. The Journal of Finance 53 (June): 879-904.

FUKAO, M. 2003. Japan's lost decade and its financial system. The World Economy 26 (March): 365-384.

Gramlich, J. D., P. LIMPAPHAYOM, AND S. G. RHEE. 2004. Taxes, keiretsu affiliation, and income shifting. Journal of Accounting and Economics 37 (June): 203-228.

Hawkins, D., K. Ramanna, N. Sato, And M. YamaZaki. 2011. Deferred tax assets in Basel III: Lessons from Japan. Cases, Harvard Business School.

Hoshi, T., AND A.K. KashyaP. 2001. Corporate Financing and Governance in Japan: The Road to the Future. Cambridge, MA : The MIT Press.

Hoshi, T., A. K. KASHYAP, AND D. SCHARFSTEIN. 1990. The role of banks in reducing the costs of financial distress in Japan. Journal of Financial Economics 27 (September): 67-88.

Kaplan, S. N., AND B. A. Minton. 1994. Appointments of outsiders to Japanese boards: Determinants and implications for managers. Journal of Financial Economics 36 (October): 225-258.

Kato, K., D. J. Skinner, AND M. KunimuRA. 2009. Management forecasts in Japan: An empirical study of forecasts that are effectively mandated. The Accounting Review 84 (September): 1575-1606.

KATO, K., M. LI, AND D. J. SKINNER. 2011. Is Japan really a "Buy"? The corporate governance, cash holdings, and economic performance of Japanese companies. Working Paper, University of Chicago.

Miller, G. S., AND D. J. SKINNER. 1998. Determinants of the valuation allowance for deferred tax assets under SFAS No. 109. The Accounting Review 73 (April): 213-233.

Murase, H., S. NumATA, AND F. TAKEDA. 2011. Reputation of low-quality Big 4 and Non-Big 4 auditors: Evidence from auditor switches of former ChuoAoyama clients. Working Paper, Universiyt of Tokyo.

NuMATA, S., and F. TAKADA. 2010. Stock market reactions to audit failure in Japan: The case of Kanebo and ChuoAoyama. The International Journal of Accounting 45 (June): 175-199.

PATELL, J. M. 1976. Corporate forecasts of earnings per share and stock price behavior: Empirical tests. Journal of Accounting Research 14 (Autumn): 246-276.

Penman, S. H. 1980. An empirical investigation of the voluntary disclosure of corporate earnings forecasts. Journal of Accounting Research 18 (Spring): 132-160.

PINKOWITZ, L., AND R. WiLLIAMSON. 2001. Bank power and cash holdings: Evidence from Japan. The Review of Financial Studies 14 (October): 1059-1082.

SKINNER, D. J. 2008. The rise of deferred tax assets in Japan: The role of deferred tax accounting in the Japanese banking crisis. Journal of Accounting and Economics 46 (December): 218-239.

SKINNER, D. J., AND S. SRINIVASAN. 2011. Audit quality and auditor reputation: Evidence from Japan. Working Paper, University of Chicago .

TANG, V. W. 2011. Isolating the effect of disclosure on information risk. Journal of Accounting and Economics 52 (June): 81-99.

VERRECCHIA, R. E. 1983. Discretionary disclosure. Journal of Accounting and Economics 5 : 179-194. 
Weber, J., M. Willenborg, AND J. ZHANG. 2008. Does auditor reputation matter? The case of KPMG Germany and ComROAD AG. Journal of Accounting Research 46 (September): 941-972.

YAMAJI, H. 1999. Interaction between Japanese accounting and economic structures. In: SundER. S., AND H. YAMAJI. The Japanese Style of Business Accounting. Westport, CT : Quorum Press. 